\title{
Cuts reversed in Canada's new budget
}

[MONTREAL] The most extensive lobbying ever conducted by Canada's research scientists has resulted in a substantial increase in federal funding for the three major grants councils - the first increase in three years.

After a period of steady decline, the councils' overall funding will rise in one step by 14 per cent over this year's figures. The increases appear in the country's first balanced budget in 29 years, presented last week by the governing Liberal party.

The Medical Research Council's (MRC's) budget for 1998-99 is to rise from C $\$ 238$ million (US\$167 million) to C $\$ 267$ million, rather than falling as planned to C\$227 million. The figures for the following two years are C $\$ 270$ million instead of C $\$ 226$ million for 1999-2000, and C\$276 million instead of C\$226 million for 2000-2001.

The Natural Sciences and Engineering Research Council budget will receive an even greater rise, to $\mathrm{C} \$ 494$ million instead of C\$423 million in 1998-99, C\$495 million instead of $\mathrm{C} \$ 423$ million the following year and $\$ 501$ million instead of $\mathrm{C} \$ 416$ million the year after that. The current budget is C $\$ 434$ million.

The Social Sciences and Humanities Research Council budget rises will be C $\$ 101$ million, C\$101 million and C\$103 million.
The differences in rate of increase between the three councils result from a decision to give each the same share of the overall research budget this year as it received in 1995, according to John Manley, the industry minister.

An important factor in the success of the lobbying was a mass campaign by bench scientists of letter-writing and visits to members of parliament and ministers.

The increases have been widely welcomed by the scientific and academic communities. But some point out that the government is just restoring the grants council budgets to their 1994-95 levels, without taking inflation into account. Others complain at the enormous disparity that remains in per capita funding between Canada's MRC and the US National Institutes of Health (NIH) - a ratio of about 1:8 (see Nature 390,$210 ; 1997$ ). The NIH competes in the same areas of research with grants on average one-third higher, making it easier for the NIH to attract top scientists.

Despite such reservations, Canadian medical science benefited immediately from the budget changes. After the last meeting of its peer-review panel in September, the MRC was forced to cut by 26 per cent the number of projects it had approved because of lack of funds. Two days after the budget was announced, the council confirmed that 109 of these projects would be funded, and extended another 26 from one to three years. Funding was also announced for a postponed C $\$ 500$ million clinical trial.

The budget also includes the creation of a C $\$ 2.5$ billion Canada Millennium Scholarship Foundation to provide more than 100,000 scholarships a year to low- and middle-income students. This was denounced by Quebec separatists as an intrusion into provincial jurisdiction, but praised by others.

New tax measures will help postsecondary students. An extra C\$205 million over three years will expand a programme to provide access to the Internet by schoolchildren and others.

Climate-change projects will receive $\mathrm{C} \$ 50$ million a year for three years, plus C\$34 million a year through the National Research Council's Industrial Research Assistance Program. The latter is to help businesses foster technologies for using energy and natural resources more efficiently and preventing pollution. But the relatively small size of this contribution to Canada's commitment at the Kyoto climate conference was derided by Jim Fulton of the Suzuki Foundation, an environmental action group. DavidSpurgeon

\section{Australia urged to avert collapse of university science}

[SYDNEY] Australian universities are calling on the government to rescue academic science from what John Niland, the new president of the Australian Vice-Chancellors' Committee, describes as an impending "national emergency akin to a natural disaster". This marks the first time the 36 member universities have united in support of a single field of study and research.

Niland, a professor of industrial relations and vice-chancellor of the University of New South Wales, delivered the challenge in Canberra last week in a televised address to a forum of academic and business leaders organized by the Federation of Australian Scientific and Technological Societies (FASTS).

John Rice of Flinders University, president of the Australian Council of Deans of Science, says "university science is in danger of spiralling out of control". He says the government is making "fundamental errors in believing universities are tertiary high schools whose sole customers are undergraduate students, and that research funding can be picked up by the private sector".

Niland says the "deep trouble" facing science is being felt most in "the very foundations of science" - physics,

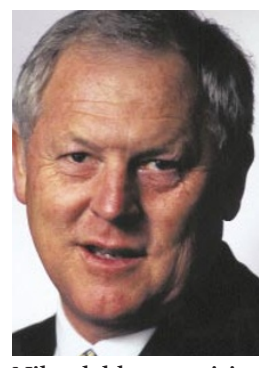

Niland: blames crisis on government cuts. mathematics and chemistry - where student interest is low, rather than in computer science or the life sciences where enrolments have grown.

Niland says a public opinion survey identified the following to the low morale in science: - a sharp increase in tuition fees - from $\mathrm{A} \$ 2,250$ (US\$1,512) in 1996 to A \$4,779 (US\$3,211) in 1997;

- fewer teaching staff — student/staff ratio rose from 12.3 in 1988 to 16.7 in 1997; - ageing facilities (universities receive only about 70 per cent of the funding of those in the United Kingdom and Canada); and - difficulties of beginning a research career as grants become harder to obtain.

According to Niland, a pass degree in accounting or law can lead to twice the salary of a professorship in science. An international index of salaries in research and development shows that, for every A $\$ 100$ paid to the average Australian scientist, the United Kingdom pays A \$104, France A \$116, the United States A \$141, Japan A \$158, Hong Kong \$166 and Germany A 170.

Niland claims "the crisis for science" is a result of government cuts to the university sector. He calculates from the government's current budget plans that the cuts will amount to 30 per cent from 1997 to 2001 if the anticipated growth in national productivity is included.

The government argues that the research situation in universities is far from critical. In a statement to the forum, education minister David Kemp wrote of "modest reductions" in the 1996 budget which mean that operating grants "will fall by less than one per cent between 1996 and 2000". Kemp has not responded to the campaign, which is pressing him to restore science funding to international levels in the May budget. The government plans to use the budget to return public finances from deficit to surplus.

Others say that universities need to develop some self-criticism, in addition to targeting the government. Peter Cullen, president of FASTS, says universities must not only press for better funding: "They need to be rattled by this crisis into reshaping curricula and organization into a more effective balance between the basic and applied sciences."

Peter Pockley 